\title{
Identifying Cell-related Misconceptions among Fifth Graders and Removing Misconceptions Using a Microscope
}

\author{
Mehmet Akif Haşiloğlu, ${ }^{1, *}$, Selma Eminoğlu \\ ${ }^{1}$ Education Faculty, Ağrı İbrahim Çeçen University, Turkey \\ ${ }^{2}$ M.E.B Teacher of Science, Turkey
}

Copyright $\bigcirc 2017$ by authors, all rights reserved. Authors agree that this article remains permanently open access under the terms of the Creative Commons Attribution License 4.0 International License

\begin{abstract}
The aim of this study is to identify cell-related misconceptions among fifth graders attending middle schools in Turkey and examine the impact of microscopy on the elimination of these misconceptions. The study was conducted with the participation of 87 fifth grade students (schoolchildren are nearly 11 years old) attending a middle school in Ağrı province of Turkey in the academic year 2015-2016. The research was designed as a case study and data were collected using a test with 4 diagnostic and drawing items. Data analysis showed that the students had cell-related misconceptions. Prior to instruction with a microscope, most students thought an onion cell was shaped like an onion and it was a cooking ingredient their mothers used. They said that a leaf cell was shaped like a leaf and described it as a leaf on a tree. They described bacteria as living things with organs and limbs, like animals. They drew and described bread mold as a loaf of bread. Most of these misconceptions were found to disappear after learning with a microscope.
\end{abstract}

Keywords Middle School, Science Education, Misconception, Microscope, Sell, Drawing

\section{Introduction}

Science education is a discipline that provides students with the necessary foundation to allow them to conceptualize natural phenomena, and form connections between them. (Ünal \& Ergin, 2006). The cell, one of the fundamental concepts of science, has applications in many areas, from medicine to biology and from health to daily life, and is a concept about which it is important to learn (Yüce, Önel \& Bekis, 2016).

The discovery and examination of the cell was made possible by the invention of the microscope in 1560 , and its subsequent development in the 1600s. Cell walls were first observed by Robert Hooke in 1665, and live cells were first observed by means of a microscope with lenses, developed by Antoni van Leeuwenhoek. The use of the electron microscope in the field of biology in the 1950s made it possible to examine many cellular organelles that were difficult to see using light microscopes (Reece, Urry, Cain, Wasserman, Minorsky \& Jackson, 2013).

Cells are usually spherical, oval, cubic, flat, prismatic, shuttle-like, star-like or pyramidal in shape, and their sizes vary between 15-20 microns. The sizes of some cells are beyond this range. Most cells are colorless, but some appear brown, green or black, depending on the color pigments in their cytoplasm (Karol, Ayvalı \& Suludere, 1995; Aktümsek \& Konuk, 2010; Reece Urry, Cain, Wasserman, Minorsky \& Jackson., 2013).

In science education, some structures that are difficult to see with the naked eye (cell, tissue, stoma, etc.) can be visualized with the help of a microscope; a basic laboratory instrument (Dökme, Doğan \&Yılmaz, 2010; Green \& Smith III, 2005; Sinsel, 2010; Dikmenli, Türkmen \& Çardak, 2002; Demirbaş \& Pektaş, 2010). The microscope is described as "an optical instrument that comprises a lens system and enables the examination of animate or inanimate objects that are too small to be seen with the naked eye" (Özata \& Türe, 1999; Dökme, Doğan \& Yılmaz, 2010; MEB, 2011).

Many primary schools have microscopes (Akpınar \& Turan, 2002; Demir, Böyük \& Koç, 2011) and, like other technological tools, they facilitate understanding when used in class (Yavuz \& Coşkun, 2008). Flick \& Bell (2000) underline the importance of the teachers' use of a microscope in the classroom, in terms of their application in science and technology.

The cell is the basic structural and functional unit of any living organism, so it is crucial that students have a good grasp of this concept. Concepts are the foundation of 
knowledge, and help people to learn, classify and organize. Concepts, which are mental tools that allow people to form thoughts, transform detailed information into usable units (Senemoğlu, 2001, 513).

A misconception, on the other hand, can be defined as learning a concept in such a way that does not correspond to currently hold scientific theory (Skelly, 1993). Prior to learning science at school, students form ideas about things during interactions with their environments (Baxter, 1989). The ideas they form as a result of these experiences or observations are far from being scientific (Sewell, 2002). The various conceptions held by students as a result of their experiences create obstacles to their understanding of the topics, and sometimes prevent meaningful learning (Tekkaya \& Balc1, 2003).

Identifying and correcting misconceptions is important, in terms of ensuring subsequent learning. Correcting a misconception is usually more difficult than teaching fresh knowledge. As a consequence, studies need to be conducted on how best to correct misconceptions. Diagnostic tests and drawings are important methods in identifying and correcting misconceptions (White \& Gunstone, 1992; Schmidt, 1997; Ayas, Karamustafaoğlu, Cerrah \& Karamustafaoğlu, 2001).

Diagnostics tests can be paper and pencil open ended tests or multiple choice tests. Open ended tests allow students to explain all of their knowledge concerning the question, together with their reasoning. This makes it possible to identify the misconceptions held by the student. Distractors in multiple choice tests are based on answers given by students to pilot questions or other open-ended questions (Taber, 1999).

Drawings are used to learn about students' knowledge, misconceptions and conceptual changes (White \& Gunstone, 1992). Drawings allow students to express their knowledge and conceptions without being limited by words (Ayas, 2006). Drawings are effective and efficient when compared with other methods to identify acquired knowledge, in that they take less time, contain a lot of information, and are easy to process (Atasoy, 2004). This method allows the students who avoid answering verbal questions to give their answers simply and quickly with drawings (Thomas \& Silk, 1990).

In recent years, identifying students' misconceptions on the basis of their drawings has become an important method used in many studies (Popov, Zackrisson, \& Olofsson, 2001; Reiss \& Tunnicliffe, 2001; Prokop \& Fancovicova, 2006; Zoldosova \& Prokop, 2007; Acar \& Tarhan, 2008; Bartoszeck, Machado \& Amann-Gainotti, 2008; Kara, Avcı \& Çekbaş, 2008; Köse, 2008; Çardak, 2009; Özden, 2009; Uzunkavak, 2009a, Uzunkavak 2009b; Patrick \& Tunnicliffe, 2010; Çelikler \& Topal, 2011; Taştan Kırık \& Kaya, 2014; Yörek, 2010; Yüce, Önel \& Bekis, 2016). Relevant studies in the literature examine how primary school students' perceive and interpret the cell (Taştan Kırık \& Kaya, 2014), and try to measure students' level of conceptual knowledge by looking at their drawings of animal cells and how they identify and name cellular organelles (Yüce, Önel \& Bekis, 2016). However, there is a lack of research on how fifth grade students imagine microscopic organisms prior to and after using a microscope. This study aims to identify misconceptions about the cell, a fundamental science concept, and examine the impact of the microscope in removing these misconceptions. To this end, the study uses student drawings and a diagnostic test.

\section{Materials and Methods}

This study used qualitative methods, and was designed as a case study, which is a descriptive research method (Çepni, 2007). The case study design was preferred because it allows the researcher to examine in depth, on the basis of answers to 'why' and 'how' questions, a phenomenon or event that is not under their control. A case study design makes it possible to collect in-depth information in line with the purposes of the study, in a relatively short time scale (Yin, 2003; Çepni, 2010).

\section{Sample of the Study}

The universe of the study was fifth grade students attending the middle school in Ağr province of Turkey in the 2015-2016 academic years, and the sample comprised a total of 87 fifth grade students (schollchildren are nearly 11 years old).

\section{Development of the Data Collection Instrument}

Data were collected using a test with 4 diagnostic and drawing items. Items in the data collection instrument were as follows:

1. Draw an onion cell and explain why you made this drawing.

2. Draw a leaf cell and explain why you made this drawing.

3. Draw a bacterial cell and explain why you made this drawing.

4. Draw a bread mold cell and explain why you made this drawing.

\section{Data Collection}

The data collection instrument was first administered in classes where the study took place, prior to instruction with a microscope, to measure students' levels of understanding concerning the topic of cells. Then, over the following two weeks, students were instructed using a microscope, allowing them to observe onion cells, leaf cells, bacterial cells and bread mold cells, in line with the purposes of the study. After two weeks, the same data collection instrument was administered to the same participants to 
examine their conceptions and definitions.

\section{Data Analysis}

This study used descriptive analysis, in which the aim of the researchers was to summarize and interpret collected data on the basis of previously defined themes, make frequent direct quotations, and organize and present their findings to the readers with accompanying comments (Yıldırım \& Şimşek, 2006). Students' verbal explanations and drawings on the data collection instrument were evaluated separately. Verbal answers were classified as "Relevant", "Irrelevant", "Partially correct" and "Correct".

1. Correct: The answer given by the student contains all the scientific information asked by the question.

2. Partially Correct: The answer given by the student is scientifically correct, but provides only part of the information asked in the question.

3. Partially Irrelevant: The answer given by the student is not completely wrong; it contains information that is partially relevant to the correct answer.

4. Irrelevant: These are answers that contain student narratives and cell definitions that do not overlap with scientific facts.

Drawings were classified as "correct", "partially correct", "partially incorrect" and "incorrect". Descriptive statistical analysis was made in the form of frequencies and percentages.

\section{Results}

The findings of the study are presented in the form of an analysis of the responses to open ended questions and drawings, accompanied by sample answers. Findings on the students' levels of conceptual understanding concerning onion cells, leaf cells, bacterial cells and bread mold cells, based on an analysis of their responses to open ended questions, are presented in Table 1.

Table 1. Descriptive statistics concerning students' explanations of the concepts prior to and following microscope observation

\begin{tabular}{|c|c|c|c|c|c|}
\hline & & $\begin{array}{r}\text { Studen } \\
\text { Mic }\end{array}$ & $\begin{array}{l}\text { ns Prior to } \\
\text { ervation }\end{array}$ & $\begin{array}{r}\text { Student } \\
\text { Micro }\end{array}$ & $\begin{array}{l}\text { ions After } \\
\text { ervation }\end{array}$ \\
\hline & & f & $\%(n=87)$ & f & $\%(n=87)$ \\
\hline & Correct & 0 & 0 & 64 & 73.5 \\
\hline ONU & Partially correct & 2 & 2.3 & 12 & 13.8 \\
\hline GIVIUTV CLEL & Partially irrelevant & 8 & 9.2 & 8 & 9.2 \\
\hline & Irrelevant & 77 & 88.5 & 3 & 3.4 \\
\hline & Correct & 0 & 0 & 59 & 67.8 \\
\hline 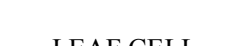 & Partially correct & 1 & 1.1 & 18 & 20.7 \\
\hline LEAT CELL & Partially irrelevant & 10 & 11.5 & 7 & 8 \\
\hline & Irrelevant & 76 & 87.3 & 3 & 3.4 \\
\hline & Correct & 0 & 0 & 51 & 58.6 \\
\hline RACTEPIAI CEIJ & Partially correct & 3 & 3.4 & 22 & 25.3 \\
\hline DAC ILNAAL CLLL & Partially irrelevant & 18 & 20.7 & 12 & 13.8 \\
\hline & Irrelevant & 66 & 75.8 & 2 & 2.3 \\
\hline & Correct & 0 & 0 & 65 & 74.7 \\
\hline RPEA M MO & Partially correct & 9 & 10.3 & 11 & 12.6 \\
\hline DKEAD IVIULD & Partially irrelevant & 45 & 51.7 & 9 & 10.3 \\
\hline & Irrelevant & 33 & 38 & 2 & 2.3 \\
\hline
\end{tabular}


Prior to being taught with a microscope, $88.5 \%$ of the participants' explanations on onion cells were irrelevant, and $0 \%$ of the students were able give the correct explanation. After learning with a microscope, the ratio of irrelevant explanations decreased to $0 \%$, and the ratio of correct explanations increased to $73.5 \%$. The percentage of partially irrelevant answers remained the same (8\%), whereas the percentage of partially correct answers increased from $2.3 \%$ to $13.8 \%$ after learning with a microscope. These findings indicate that observing the onion cell under a microscope improved the students' explanations regarding the concept of an onion cell.

Prior to using microscope

Sample irrelevant response:

S58: "Onion is added to meals."

Sample partially correct response:

S41: "Onions have cells."

\section{After using microscope}

Sample correct response:

S58: "It contains a nucleus and oval-shaped things."

Sample partially correct response:

S41: "Onion cell is checkered and its nucleus is like a dot."

Prior to observing the leaf cell under the microscope, $87.3 \%$ of students made irrelevant explanations, $11.5 \%$ made partially irrelevant explanations, $1 \%$ made partially correct explanations and $0 \%$ made correct explanations. After observing the leaf cell under the microscope, the ratio of students making correct explanations increased to $67.8 \%$ and the ratio of partially correct answers increased to $20.7 \%$, whereas the ratio of partially irrelevant answers decreased to $8 \%$ and the ratio of irrelevant answers decreased to $3.4 \%$. Sample student answers prior to and following teaching with the microscope:

Prior to using microscope

Sample irrelevant response:

S32: "Leaves are for bugs."

Sample partially irrelevant response:

S14: "Leaves grow on trees and they turn yellow and fall in autumn."

Sample irrelevant response:

S68: "Leaves and trees very beautiful."
After using microscope

Sample correct response:

S32: "Leaf cell has a cell wall with tangled lines and dots."

Sample partially correct response:

S14: "It was just like a honeycomb."

Sample irrelevant response:

S68: "Leaf cell is very good and arrive."

Prior to observing bacteria under the microscope, $87.3 \%$ of explanations provided by the students were irrelevant, $11.5 \%$ were partially irrelevant, $1.1 \%$ were partially correct and $0 \%$ was correct. After the students observed the bacteria under the microscope, the ratio of correct explanations concerning bacteria increased to $6.78 \%$ and the ratio of partially correct explanations increased to $20.7 \%$; whereas, the ratio of irrelevant explanations decreased to $3.4 \%$, and the ratio of partially irrelevant explanations decreased to $8 \%$.

Prior to using microscope

Sample irrelevant response:

S56: "I did this because I don't know what bacteria are like."

Sample partially correct response:

S73: "I think they are colorful bacteria formed in the human body."

Sample partially irrelevant response:

S77: "Dirt on our hands is called bacteria."
After using microscope

Sample correct response:

S56: "They are organisms that are too small to be seen with the naked eye"

Sample correct response:

S73: "Bacteria are small organisms and they are very difficult to observe."

Sample partially correct response:

S77: "Bacteria have small, dirt-like things."

Prior to observing bread mold under the microscope, $38 \%$ of student explanations concerning the bread mold were irrelevant, $51.7 \%$ were partially irrelevant, $10.3 \%$ were partially correct and $0 \%$ was correct. After learning with a microscope, the ratio of correct explanations concerning the bread mold increased to $74.7 \%$ and the ratio of partially correct explanations increased to 12.6 , whereas the ratio of partially irrelevant explanations decreased to $10.3 \%$, and the ratio of irrelevant explanations decreased to $2.3 \%$.

Prior to using microscope

Sample irrelevant response:

S52: "It is a bread that turns bread and mold"

Sample partially irrelevant response:

S51:"If we leave the bread in a place, don't eat it and don't touch it for a long time, it results in molding."

Sample partially correct response:

\section{After using microscope}

Sample correct response:

S52: "There was something like into pollen." a green dot, a spore, something hairy, a grayish hyphae."

Sample correct response:

Ö51: "Here we saw spores on green structures and the cotton-like structures are hyphae."

Sample correct response: 
S31: "Bread mold forms colors such as white, black and green."
Ö31: "The dots are called spores, the hairs are called hyphae, it had green dots and gray and white colors."

Table 2. Descriptive statistics concerning student drawings prior to and following microscope observation

\begin{tabular}{|c|c|c|c|c|c|}
\hline & \multicolumn{2}{|c|}{$\begin{array}{c}\text { Students' Drawings Prior to Microscope } \\
\text { Observation }\end{array}$} & \multicolumn{2}{|c|}{$\begin{array}{c}\text { Students' Drawings After Microscope } \\
\text { Observation }\end{array}$} \\
\hline & & f & $\%(n=87)$ & f & $\%(n=87)$ \\
\hline \multirow{4}{*}{ ONION CELL } & Correct & 0 & 0 & 50 & 57.5 \\
\hline & Partially correct & 3 & 3.4 & 33 & 38 \\
\hline & Partially incorrect & 4 & 4.6 & 3 & 3.4 \\
\hline & Incorrect & 80 & 92 & 1 & 1.5 \\
\hline \multirow{4}{*}{ LEAF CELL } & Correct & 0 & 0 & 42 & 48.3 \\
\hline & Partially correct & 1 & 1.5 & 42 & 48.3 \\
\hline & Partially incorrect & 4 & 4.6 & 2 & 2.3 \\
\hline & Incorrect & 82 & 94.2 & 1 & 1.5 \\
\hline \multirow{4}{*}{ BACTERIAL CELL } & Correct & 0 & 0 & 61 & 70 \\
\hline & Partially correct & 3 & 3.4 & 23 & 26.4 \\
\hline & Partially incorrect & 3 & 3.4 & 2 & 2.3 \\
\hline & Incorrect & 81 & 93 & 1 & 1.5 \\
\hline \multirow{4}{*}{ BREAD MOLD } & Correct & 0 & 0 & 41 & 47.1 \\
\hline & Partially correct & 0 & 0 & 38 & 43.6 \\
\hline & Partially incorrect & 10 & 11.5 & 6 & 6.9 \\
\hline & Incorrect & 77 & 88.5 & 2 & 2.3 \\
\hline
\end{tabular}

Based on the reported data, the following observations can be made. Prior to observing onion cells under the microscope, $92 \%$ of the student drawings were incorrect, $4.6 \%$ were partially incorrect, $3.4 \%$ were partially correct and $0 \%$ was correct. After learning with the microscope, the ratio of correct drawings increased to $57.5 \%$ and the ratio of partially correct drawings increased to $38 \%$, whereas the ratio of partially incorrect drawings decreased to 3.4 and the ratio of incorrect drawings decreased to $1.5 \%$. These findings indicate that teaching, which involved having students observe the onion cell under the microscope, removed misconceptions in their minds to a significant extent. Figure 1 presents sample drawings of the onion cell made by students.

\begin{tabular}{|c|c|c|c|c|}
\hline Onion Cell & Correct & Partially correct & Partially incorrect & Incorrect \\
\hline \multirow{2}{*}{ Initial drawings } & & & & \\
\hline \multirow{5}{*}{ Subsequent drawings } & & & & \\
\hline & & & & \\
\hline
\end{tabular}

Figure 1. Student drawings of the onion cell

Initially, $94.2 \%$ of the students' drawings of the leaf cell were incorrect, $4.6 \%$ were partially incorrect and $1.5 \%$ were partially correct; whereas, the percentage of students who made the correct drawing was $0 \%$. Following lessons that 
involved the students looking at the leaf cell under the microscope, $48.3 \%$ of student drawings were correct, $48.3 \%$ were partially correct, $2.3 \%$ were partially incorrect and $1.5 \%$ were incorrect. These findings indicate that having the students look at the leaf cell under the microscope made their mental images more realistic concerning the leaf cell related shapes. Figure 2 presents sample drawings of the leaf cell made by students.

\begin{tabular}{|c|c|c|c|c|}
\hline Leaf Cell & Correct & Partially correct & Partially incorrect & Incorrect \\
\hline Initial drawings & & & & \\
\hline & & & & \\
\hline & & & & \\
\hline
\end{tabular}

Figure 2. Students' drawings of the leaf cell

Of the student drawings made prior to observing bacteria under the microscope, $93 \%$ were incorrect, $3.4 \%$ were partially incorrect, $3.4 \%$ were partially correct and $0 \%$ was correct. After being taught with the microscope, the ratio of correct drawings of the bacterial cell increased to $70 \%$ and the ratio of partially correct drawings increased to $26.4 \%$, whereas the ratio of partially incorrect drawings decreased to $2.3 \%$, and the ratio of incorrect drawings decreased to $1.5 \%$. The students' drawings indicated that those who previously had no idea of bacteria had acquired knowledge of bacteria after having looked at them under the microscope. Figure 3 presents sample of student drawings.

\begin{tabular}{|c|c|c|c|c|}
\hline Bacterial Cell & Correct & Partially correct & Partially incorrect & Incorrect \\
\hline Initial drawings & & & & \\
\hline & & & & \\
\hline
\end{tabular}

Figure 3. Student drawings of the bacterial cell

Prior to learning with the microscope, $88.5 \%$ of student drawings of the bread mold were incorrect and $11.5 \%$ were partially incorrect, whereas the ratio correct and partially correct drawing was $0 \%$. Following teaching that involved having the students look at the bread mold under the microscope, $47.1 \%$ of the drawings were correct, $43.6 \%$ were partially correct, $6.9 \%$ were partially incorrect, and 2.3 were incorrect. These findings indicate that after observing the bread mold under the microscope, the students formed more realistic mental images of the bread mold. Figure 4 presents sample student drawings. 


\begin{tabular}{|c|c|c|c|c|}
\hline Bread Mold & Correct & Partially correct & Partially incorrect & Incorrect \\
\hline Initial drawings & & & & \\
\hline & & & & \\
\hline
\end{tabular}

Figure 4. Student drawings of bread mold

\section{Discussions}

This study aimed to identify misconceptions about the concept of a cell among fifth grade students and to correct these misconceptions with the help of a microscope. Findings show that initially, most students described the onion cell as a cooking ingredient used by their mothers. After learning with the microscope, they described the onion cell as being checkered and having a dot-like nucleus. The incorrect drawings of the students show that they thought of the onion cell as an actual onion. After learning with the microscope, they were observed while drawing the onion cell that they saw under the microscope. These findings indicate that students had misconceptions about the onion cell, and these misconceptions were removed to a significant extent after learning with the microscope.

Data on descriptions of the leaf cell showed that most students thought of a leaf cell as a leaf on a tree. Drawings of the leaf cell showed that most students imagined the leaf cell as a leaf. After learning with the microscope, they described the leaf cell as resembling a honeycomb and having a cell wall covered with dots. These findings indicate that students had important misconceptions reflected in both their drawings and verbal explanations and using the microscope was effective in removing these misconceptions.

In their explanations concerning bacteria, students initially described bacteria as dirty animals, microbes, and organisms with organs, but after seeing them under the microscope, they described bacteria as organisms too small to be seen with the naked eye. Misconceptions reflected in descriptions, such as microbes and dirty animals, were largely removed thanks to the use of the microscope.

Student explanations about the bread mold prior to microscope observation showed that most students described the bread mold as bread, indicating a misconception. After learning with the microscope, they stated that bread mold has spores, and its hairy parts are called hyphae, this information was also reflected in their drawings. Thus, having the students look at the bread mold under the microscope resulted in them forming more accurate mental images regarding the cellular structure of a concept about which they already knew.

Based on these findings, using a microscope in teaching is recommended. In this way, students better understand the existence of organisms that are too small to be seen with the naked eye, and to form more accurate mental images of their shapes.

\section{REFERENCES}

[1] Acar, B. \& Tarhan, L. (2008). Effects of Cooperative Learning on Students' Understanding of Metallic Bonding. Resarch in Science Education. 38, 401-420.

[2] Akpinar, B., \& Turan, M. (2002). Use of Material in Science Education in Primary Schools. Presented at the V. National Science and Mathematics Education Congress. Middle East Technical University, Ankara.

[3] Aktümsek, A. \& Konuk, M. (2010). General Biology ( $3^{\text {rd }}$ Edition). Ankara: Nobel Yayın Dağıtım.

[4] Atasoy, B. (2004). Science Learning and Teaching (2 ${ }^{\text {nd }}$ Edition). Ankara: Asil Yayınevi.

[5] Ayas, A., (2006). Kavram Öğrenimi, Fen ve Teknoloji Öğretimi (Edt: S. Çepni). Pegema Yayıncılık, Ankara

[6] Ayas, A.; Karamustafağolu, S.; Cerrah, L. and Karamustafağolu, O. (2001). A Review on the Conceptual Understanding Levels and Misconceptions of Students in Science. Presented at the 10th National Education Science Congress as a Report. 
[7] Bartoszeck, A. B., Machado, D. Z. \& Amann-Gainotti, M. (2008). Representations of Internal Body Image: A Study of Preadolescents and Adolescent Students in Araucaria, Paraná, Brazil. Ciências \& Cognição. 13 (2), 139-159.

[8] Baxter, J. (1989). Children's Understanding of Familier Astronomical Events. International Journel of Science Education, 11(5), 302 -313.

[9] Çardak, O. (2009). Science Students' Misconceptions of the Life Cycle According to Their Drawings. Journal of Applied Sciences, 9 (5), 865-873.

[10] Çelikler, D. \& Topal, N. (2011, Kasım). Determination of Knowledge of Carbon Dioxide and Water Cycle of Elementary Science Teacher Candidates by Drawing. Journal of Education and Teaching Practices in the World, 1 (1).

[11] Çepni, S. (2007). Introduction to Research and Project Studies, 3rd Edition, Trabzon: Celepler Matbaacılık.

[12] Çepni, S. (2010). Introduction to Research and Project Studies ( $5^{\text {th }}$ Edition). Trabzon: Celepler Matbaacilik.

[13] Demir, S., Böyük, U., \& Koç, A. (2011). Views of science and technology teachers on laboratory conditions and use of laboratory with their tendencies to follow technological innovations. Mersin University Journal of the Faculty of Education, 7(2), 66-79.

[14] Demir, S., \& Şahin, F. (2012a). Levels of Open-Ended Experimentation of Science Teacher Candidates. Presented at The $21^{\text {st }}$ National Congress of Educational Science. Marmara University, İstanbul.

[15] Demirbaş, M., \& Pektaş, H.M. (2010). Measurement of The Skills of Turkish University Students in Using Microscopes and The Analysis of The Problems Faced in This Process. World Applied Sciences Journal, 11 (9), 1177-1182.

[16] Dikmenli, M., Türkmen, L., \& Cardak, O. (2002). Alternative Concepts Related to Microscope Studies in Biology Laboratories of University Students. Presented at the National Science and Mathematics Education Congress. ODTU, Ankara.

[17] Dökme, İ., Doğan, A., \& Y1lmaz, M. (2010). Laboratory Applications of Science Teaching I-II. Ankara: Palme Yayıncilik

[18] Flick, L., \& Bell, R. (2000). Preparing Tomorrow's Science Teachers to Use Technology: Guidelines For Science Educators. Contemporary Issues in Technology and Teacher Education, 1(1), 39-60.

[19] Gilbert, J. K.; Watts, D. M. \& Osborne, R. J. (1985). Cognitive Structure and Conceptual Change. Orlando: Academic Press.

[20] Green, S. \& Smith III, J. (2005). Small Things Draw Big Interest. Science and Children, 42 (4), 30-34

[21] Kara, İ., Avc1, E. D. \& Çekbaş, Y. (2008). Investigation of Knowledge Levels of Science Teachers' Candidates about Light Concept. Education Faculty Journal of Mehmet Akif Ersoy University, December 2008. 46-57.

[22] Karol, S., Ayval1, C. \& Suludere, Z. (1995). Cell Biology ( $3^{\text {rd }}$ Edition). Ankara: Gözde Repro Ofset.
[23] Köse, S. (2008). Diagnosing Student Misconceptions: Using Drawings as a Research Method. World Applied Sciences Journal. 3 (2), 283-293.

[24] MEB (Ministry of National Education). (2011). Secondary School Project: Laboratory Services, Microscopic Examination. 524LT0021. Ankara.

[25] Özata, A., \& Türe, C. (1999). Microscope and its Usage. M. Zor (Ed.), Laboratory Practices and Safety in Science Teaching. 1. Cilt. Eskişsehir: T.C. Anadolu University Open Education Faculty Publications.

[26] Özden, M. (2009). Primary Student Teachers' Ideas of Atoms and Molecules: Using Drawings. Education. 129(4), 635-642.

[27] Patrick, P. G. \& Tunnicliffe, S. D. (2010). Science Teachers' Drawings of What is Inside the Human Body. Journal of Biological Education, $44 \quad$ (2), 81-87. http://dx.doi.org/10.1080/00219266.2010.9656198

[28] Popov, O., Zackrisson, I. \& Olofsson, K.U. (2001). Communicating Physics in Drawings and Words: The Case of Prospective Science Teachers. Department of Mathematics, Technology and Science Education, Teacher Education, Umea University.

[29] Prokop, P. \& Fancovicova, J. (2006). Students' Ideas About The Human Body: Do They Really Draw What They Know? Journal of Baltic Science Education. 2 (10), 86-95

[30] Reece, J.B., Urry, L.A., Cain, M.L., Wasserman, S.A., Minorsky, P.V. \& Jackson, R.B. (2013). Campbell Biology ( ${ }^{\text {th }}$ Edition), (Çev. Ed. Ertunç Gündüz and İsmail Türkan). Ankara: Palme Yayıncılık.

[31] Reiss, M. J. \& Tunnicliffe, S. D. (2001). Students' Understanding of Human Organs and Organ Systems. Research in Science Education, 31, 383-399.

[32] Schmidt, H. J. (1997). Students' Misconceptions: Looking for A Pattern. Science Education. 81, 123-135

[33] Senemoğlu, N. (2001). Development and Learning from the Theory to Practice. Ankara: Gazi Kitabevi.

[34] Sewell, A. (2002). Constructivism and Students' Misconceptions. Australian Science Teachers' Journal, 48(4), 24-28

[35] Sinsel, J. (2010). Using Microscopes in the Classroom. Taken fromhttp://www.lessonplanet.com/article/elementary-scienc e/using-microscopes-in-the-classroom. In 24.05.2012.

[36] Skelly, K, M. (1993). The Development and Validation of A Categorization of Sources of Misconceptions in Chemistry. Third Misconceptions Seminar Proceedings.

[37] Taber, K. S. (1999). Ideas about Ionization Energy: A Diagnostic Instrument. School Science Review. 81(295), 97-104.

[38] Taştan Kırık, Ö. \& Kaya, H. (2014). A Qualitative Study Concerning the $6^{\text {th }}$ Grade Students' Conceptual Structures about the Cell Concept. International Online Journal of Educational Sciences, 6(3), 737-760.

[39] Tekkaya, C., \& Balc1, S. (2003). Detection of Misconceptions of Students in Photosynthesis and 
Respiration in Plants. Journal of Hacettepe University Education Faculty, 24(24).

[40] Thomas, G. V. \& Silk, A. M. J. (1990). An Introduction to The Psychology of Children's Drawings. Hemel Hempstead: Harvester Wheat Sheaf.

[41] Uzunkavak, M. (2009a). Comparing Students' Newton Laws with Writing and Drawing Methods. SDU International Journal of Technologic Sciences, 1 (1), 29-40.

[42] Uzunkavak, M. (2009b). Identification of Positive-Negative Separation Skills in the Concept of Work by Students in Writing and Drawing Method. SDU International Journal of Technologic Sciences 1 (2), 10-20.

[43] Ünal, G. \& Ergin, Ö. (2006). Science Education and Models. National Education Journal, 171, 188-196.

[44] White, R. \& Gunstone, R. (1992). Probing Understanding. Hong Kong: Graphicraft Ltd.

[45] Yavuz, S., \& Coşkun, A.E. (2008). Attitudes and Thoughts on the Use of Technology in Education by Students of
Primary School Teachers. Hacettepe University Education Faculty Journal, 34, 276-286.

[46] Yıldırım, A. \& Şimşek, H. (2006). Qualitative Research Methods in the Social Sciences, $6^{\text {th }}$ Edition, Ankara: Seçkin Yayınc1lik.

[47] Yin, R.K. (2003). Case Study Research: Design and Methods ( $3^{\text {rd }}$ Edt.). London: Sage Publications.

[48] Yörek, N. (2010). Determination of Conceptual Understanding Levels of Students in $9^{\text {th }}$ and $11^{\text {th }}$ Grade Students by Cell Drawings. Buca Eğitim Fakültesi Dergisi, (22).

[49] Yüce, Z., Önel, A. \& Bekis, E. S. (2016). Determination of the Conceptual Knowledge Levels of the Secondary School Students by Their Cellular Drawings. Mersin Üniversitesi Eğitim Fakültesi Dergisi, 12(2).

[50] Zoldosova, K. \& Prokop, P. (2007). Primary Pupils' Preconceptions about Child Prenatal Development. Eurasia Journal of Mathematics, Science \& Technology Education, $3(3), 239-246$ 